\title{
IMPROVING LISTENING ABILITY BY ACTIVATING STUDENTS' BEFORE KNOWLEDGE
}

\author{
Ridwan Kurniadi ${ }^{1}$, Rizal Mulyana ${ }^{2}$, Odo Fadloeli ${ }^{3}$ \\ ${ }^{1}$ IKIP Siliwangi \\ ${ }^{2}$ IKIP Siliwangi \\ ${ }^{3}$ IKIP Siliwangi \\ ${ }^{1}$ ridwankurniadi23@gmail.com, ${ }^{2}$ rizaalmulyana@gmail.com, ${ }^{3}$ oddofadloeli@upiedu.com
}

\begin{abstract}
This research paper aims at finding whether the students' ability in listening can be improved by activating students' previous knowledge. The research was conducted at SMK Budi Bakti Utama. The research used random sampling class and test by giving pretest and post test. Two classes are experimental class and control class, when the experimental class got a better score than control class. The experimental class was increased in listening ability. Most of the student's of experimental class students' stay in fair category.
\end{abstract}

Keywords: Improving, Listening, Activating

\section{INTRODUCTION}

Listening is the ability which is brought by receiving message in spoken form and therefore often referred to as receptive skill (Harmer, 2001). Although it is considered to receive ability, it is necessary to procces decoding the message from the speaker. By emphasizing the role of resonable input, second language acquisition research has provided a great incentive to hear. On the other side, listening is considered and more important inforeign language in classrooms.

Teaching listening has a greater interest in 2018 than in the past, now university entrance exams, exiting exams, and others.The exam often includes a listening component, recognizing that listening ability is the core of component in a second language proficiency, and it also describes the acceptance that if listening is not examined, the teacher will not teach it. Listening is one of the receptive abilities and as such it incriminate students in capturing and understanding the input of English (Arono, 2014). It is in linen with the statement of Broughton, et al. (1980: 65) cited in Aryana and Apsari (2018) that listening calls for active participation in the communication between the participants and a receptive skill is involved in understanding the message.

Listening is perhaps more difficult than reading because students often recognize the written word more easily than they recognize the spoken word. In another case in reading, students can go back and read a expression where as with listening they only get one chance (Hadley., 2001). Because of these issues, many students find some difficulties in listening.

Listening task can be very disappointing and discouraging, especially if the student had a negative experience . more importanly giving our students more chance to practice listening ability in a supportive environment that's can help the students' to learn more. This means that we guide them how to use the recording, preteach language and highlight the essential points of the recording. This is in contrast to testing, where the teacher plays the recording and the 
students listen and answer the questions. But, careful observation of the practice of collage English teaching has found that teaching listening ability is still weak in the language teaching procces (Vaugh, 2009). Although the students' have a skill the basic element of English grammar and vocabulary, their listening undertanding is often weak. Through a systematic study of the stages of basic English language teaching at the university it has been recognized that while the ability of students to be integrated in writing context, reading context, translating has increased, their listening and speaking abilities have been left behind the teaching. The key factor that has been familiar in the preparation studies is students' limited listening comprehension (Brown, 2001).The next step, Listening in another language is opinion as a hard job (Nurpahmi, 2018). The study says that the researcher was held in field research found that, students need to repeat to play the video four times to identify information required, while in normal listening test the recording just plays once.

Listening is a mental process that incriminate critical element in the competent language performance of learners. In the process of understanding, listeners use both bottom-up and topdown processes to understand. Knowing the context of a listening text and the goal for listening greatly reduces the responsibility of understanding. Teachers can help students develop strategies with such activities as controlled practice and open-ended listening. Students may have restricted common knowledge about a topic. Providing knowledge input will build up their confidence for face to face with listening. Sholihah (Utami, 2012) says the only way to make listening easier is by applying what we learn about activating before knowledge, helping students arrange their studies by having a certain thought about their goal for listening ability, and if speaking also has a direction of the classroom, using a good structured speaking tasks informed by research.

\section{METHOD}

The researchers used quantitative research method. In this project ,we use cluster random sampling method in which researcher used random sampling class and test by pretest and post test to two class is experimental class and control class, when the experimental class has got a better score than control class. And experimental class was increased in listening ability. Most of the students' of experimental class stay in fair category.

\section{RESULTS AND DISCUSSION}

\section{Results}

We can check on the data analysis and it shows that the students' pretest score and percentage of listening for experimental and control class are not the same. 
Table 1 The Percentage of Students' Pretest Score of Listening

\begin{tabular}{|c|c|c|c|c|c|}
\hline \multirow{2}{*}{ Classification } & \multirow{2}{*}{ Score } & \multicolumn{2}{|c|}{ Experimental Class } & \multicolumn{2}{|c|}{ Control Class } \\
\hline & & Frequency & Percentage & Frequency & Percentage \\
\hline Very Good & 4 & - & - & - & - \\
\hline Good & 3 & 6 & 15 & 7 & 17.50 \\
\hline fair & 2 & 32 & 85 & 33 & 82.50 \\
\hline Poor & 1 & - & - & - & - \\
\hline Very Poor & 0 & - & - & - & - \\
\hline Total & & 40 & $100 \%$ & 40 & $100 \%$ \\
\hline
\end{tabular}

Based on the table 1 above, it is known that most of the students for experimental class was in fair category, 32 students (85\%) obtain fair and 6 student $(85 \%)$ obtain good score in the control class the score was in average category, from the 40 respondents, we know the data indicated that 33 students $(82.50 \%)$ obtain average and 7 students $(17.50 \%)$ obtain good score.

Based on the data it means that two classes were almost the same. Both of them were classified in very poor categories as well. Furthermore, it shows the percentage of students' posttest score of listening who were learn by activating before knowledge, was different from those who were learrn without activating before knowledge.

Table 2 The Percentage of Students' Posttest Score of Listening

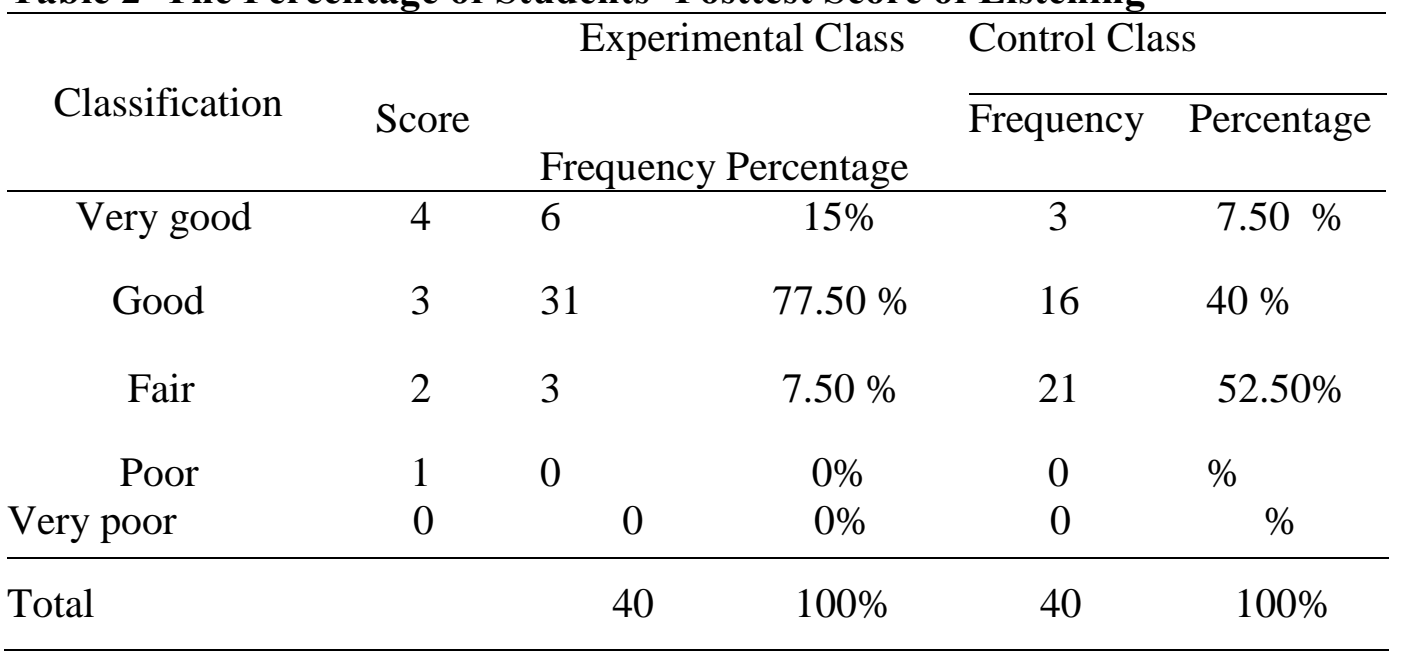

The data above shows that the Students' listening ability of experimental class in posttest increased, 31 students $(77.50 \%)$ obtain good, 6 students $(15 \%)$ obtain very good score too and 3 students $(7.50 \%)$ obtain fair score. While, in control class we have, 2 student $(7.50 \%)$ obtain very good percentage, 16 students (40\%) obtain good score classification and 21 (52.50) obtain average score.

According to the data it shows that the students score in both classes increase. The percentage of students' pretest score was obtain by the students can be seen in a table as follows: 
Table 3 The Average Score and Standard Deviation of Students' Pretest in Listening

\begin{tabular}{lcc}
\hline \multicolumn{1}{c}{ Class } & Mean Score & Standard Deviation \\
\hline Experimental & 2.13 & 7.363 \\
Control & 2.16 & 7.468 \\
\hline
\end{tabular}

The table 3 above shows that the average score of students' listening pretest of experimental class is 2.13 which is categorized as fair classification and control class is 2.16 which is categorized as fair classification too. On the other side, based on the table above, we concluded that the students' mean score of experimental class is nearly same with the control class. It means that there is not significantly different between the Students' listening ability both experimental and control classes before treatment.

Because the students pretest was nearly at the same level, the treatment was conducted to the both groups. The experimental class was taught English by activating beforeknowledge and control class was taught the same materials without activating before knowledge.

The average score and standard deviation are presented in the following table to find out the difference between the posttest score of experimental and control classes.

Table 4 The Average Score and Standard Deviation of Students' Posttest

\begin{tabular}{lcc}
\multicolumn{1}{c}{ Class } & Mean Score & Standard Deviation \\
\hline Experimental & 3.1 & 5.025 \\
Control & 2.53 & 6.827
\end{tabular}

The table 4 above shows that the average score of both groups are different after being given treatment. The average score of experimental class is 3.1 which is categorized as good and control class is 2.53 which is categorized is fair and standard deviation of experimental class is 5.025 and standard deviation of control class is 6.827 .

1. Test of significant (t-test)

Inferential analysis was used to test the hypothesis. The researcher used t-test (test of significance) for independent sample test. This is a test to know the significant difference between the result of students' average scores in posttest in control class and experimental class after being taught by activating before knowledge. The level of significance $(\alpha)=0.05$, then the result of the t-test is presented in the following table:

Table.5 The p-Value of t-test of Student Achievement on Control and Experimental Classes

\begin{tabular}{lccl} 
Variables & p-value & $(\boldsymbol{\alpha})$ & Remarks \\
\hline $\begin{array}{l}\text { Pretest of control and } \\
\text { experimental classes }\end{array}$ & 0.343 & 0.05 & $\begin{array}{l}\text { Not significantly } \\
\text { different }\end{array}$
\end{tabular}


According to the data analysis as summarized in table.5 above in pretest of control and experimental class, the researcher found that the Probability Value is higher than alpha $(\alpha)$ $(0.343>0.05)$ which means that there is no significant difference in pretest. While on posttest of control and experimental class, the researcher found that the p-value $(0.00<0.05)$ and the degree of freedom 78 .The average score of experimental and control classes in posttest were remarked significantly different. It indicated that the alternative hypothesis (H1) was accepted and, of course, the null hypothesis (H0) was rejected. It showed that the application of activating students' before knowledge in teaching listening significantly increase Students' listening ability.

This implementation that the activating students' before knowledge should be taken for granting as one of the techniques that improve students' listening ability to the participants of SMK Budi Bakti Utama. Relating to collected data through the pretest and posttest, the comparison of the improvement of students' achievement of experiment and control class can be proved by ourself to analyzing the post test result. It was concluded that after giving treatment, there was a significant progress toward students' listening ability.

The mean score of experimental and control group increased after they were given treatments. The experimental group learn by activating students; before knowledge while the control group learnt by using the conventional method. It indicates that the the application of activating students' before knowledge can improve students listening ability.

The improvement of students' listening ability was marked by the result of the posttest was happen in the both experimental and control group. But, the increasing rate of the experimental group was little bit higher than control group i think.

What is found through this research support the previous finding and theory that schemata theory can improved students listening ability. As Utami (Utami, 2012) point out that one way to make listening easier is by applying what we know about activating before knowledge, helping students arrange their learning by thinking about their goal for listening.

\section{CONCLUSION}

In this case ,we know that we can't achieve listening ability instantly, we must do a lot of activities which can support our listening ability and can improve before we learn about that knowledge itself. More importantly students must know their goal why they must improve their listening skill

\section{ACKNOWLEDGMENTS}

We would like to express our special thanks of gratitude to my instuctor teacher " Mr. Odo Fadloeli M.A " who gave us the golden opportunity to do this wonderful project on the topic "IMPROVING LISTENING ABILITY BY ACTIVATING STUDENTS' BEFORE KNOWLEDGE", which also help us in doing a lot of research. 


\section{REFERENCES}

Arono. (2014). Improving Students Listening Skill through Interactive Multimedia in Indonesia. Journal of Language Teaching and Research, 5(1), 63-69. Retrieved from https://doi.org/10.4304/jltr.5.1.63-69

Aryana, S., \& Apsari, Y. (2018). Analysing Teacher's Difficulties In Teaching Listening. ELTIN JOURNAL, Journal of English Language Teaching in Indonesia, 6(2), 100-106.

Brown, H. D. (2001). Teaching by Principles : An Interactive Approach to Language Pedagogy. In Second Edition. San Francisco: Addition Wesley Longman, Inc.

Hadley. (2001). Teaching Language in Context. In Third Edition. USA: Thomson Learning. Harmer. (2001). practice of english languange teaching. Edinburgh gate: longman.

Nurpahmi. (2018). No Title. ETERNAL (English, Teaching, Learning and Research Journal), 1(1), 28-38. Retrieved from https://doi.org/10.24252/eternal.v11.2015.a3

Utami, S. \&. (2012). Improving students' listening skill by using English songs. English Review: Journal of English Education, 3(1), 81-90. Retrieved from https://journal.uniku.ac.id/index.php/ERJEE/article/view/117/79

Vaugh, B. (2009). Strategies for Teaching Students With Learning and Behaviour Problems. In Seventh Edition. New Jersey: Pearson Education. 